Kocaeli Üniversitesi Sağlık Bilimleri Dergisi

\title{
USAGE OF PEPTIDE ANTIGENS FOR ANTIBODY-BASED BoNT DETECTION SYSTEM
}

\author{
ANTIKOR BAZLI BoNT TESPIT SISTEMI IÇIN PEPTIT ANTIJJENLERIN KULLANIMI
}

\author{
@(Deryem Işık ${ }^{1,2}$ (D) Zülal Bilici ${ }^{1,+}$, (D) Naci Çine ${ }^{2}$, (Delma Öztürk ${ }^{1,+}$
}

${ }^{1}$ TÜBİTAK, The Scientific and Technological Research Council of Turkey, Marmara Research Center, Genetic Engineering and Biotechnology Institute, Gebze, Kocaeli 41400, Turkey, ${ }^{2}$ Department of Medical Genetics and Molecular Biology, Kocaeli University, Umuttepe, Kocaeli 41100, Turkey, ${ }^{+}$The two authors are out of work now.

ORCID iD: Meryem Işı: 0000-0001-9990-6571; Zülal Bilici: 0000-0002-1957-5758; Naci Çine: 0000-0001-9063-1073; Selma Öztürk: 0000-00027949-8993

*Sorumlu Yazar / Corresponding Author: Meryem Işık e-posta / e-mail: meryem.isik@tubitak.gov.tr

Geliş Tarihi / Received: 11.05.2021 Kabul Tarihi / Accepted: 09.09.2021 Yayım Tarihi / Published: 31.10 .2021

\begin{abstract}
Objective: In the current study, we aimed to elicit a BoNT-specific immune response via using peptides designed by using bioinformatics tools instead of using intact native BoNT A toxin itself and to demonstrate the usage of these anti-peptide antibodies in a toxin detection system.

Methods: Synthetic epitopic regions specific to LC, HN and HC regions of BoNT A were selected as antigen using B cell "Epitope Prediction Tools" form IEDB and shown to be on the surface of BoNT A with a software (Discovery Studio 4.0). Selected peptides were used in mice immunizations and the interaction between developed anti-peptide antibodies and the native intact BoNT A was examined.

Results: The detection of native intact BoNT A at picogram levels per milliliter was performed with anti-peptide antibodies developed against three different peptides (P1, P2, and P3) in mice.

Conclusion: The current study shows that synthetic peptides are at least as effective as the native toxin or the toxoid itself for raising high-affinity antibodies against toxins. In addition, considering the need for a quick diagnosis of botulism and, already used test systems in which many experimental animals are sacrificed, these results demonstrate the necessity of synthetic peptide immunogens usage to reduce both the number of animals and the amount of toxin usage.
\end{abstract}

Keywords: Antibody generation, Botulinum neurotoxin A, botulism, synthetic peptides, toxin detection.

\section{$\ddot{\mathbf{O z}}$}

Amaç: Bu çalışmada, doğal yapılı BoNT A toksininin kendisi yerine biyoinformatik araçlar kullanılarak tasarlanan peptitleri kullanarak BoNT'ye özgü bir bağışıklık tepkisi ortaya çıkarmayı ve bu anti-peptit antikorlarının bir toksin tespit sisteminde kullanımını göstermeyi amaçladık.

Yöntem: BoNT A'nın LC, HN ve HC bölgelerine özgü sentetik epitopik bölgeler, IEDB'den B hücresi "Epitop Tahmin Araçları" kullanılarak antijen olarak seçildi ve bir yazılımla (Discovery Studio 4.0) BoNT A yüzeyinde olduğu gösterildi. Seçilen peptidler, fare bağışıklamalarında kullanıldı ve geliştirilen anti-peptid antikorları ile doğal yapılı BoNT A arasındaki ilişki incelendi.

Bulgular: Farelerde üç farklı peptide (P1, P2 ve P3) karşı geliştirilen anti-peptid antikorları ile mililitrede pikogram seviyelerinde doğal yapılı BoNT A'nın saptanması gerçekleştirildi.

Sonuç: Bu çalışma, sentetik peptitlerin, toksinlere karşı yüksek afiniteli antikorları geliştirmek için en az doğal toksin veya toksoidin kendisi kadar etkili olduğunu göstermektedir. Ayrıca botulizmin hızlı teşhisine duyulan ihtiyaç ve halihazırda kullanılan test sistemlerinde çok sayıda deney hayvanının kurban edildiği göz önüne alındığında, bu sonuçlar hem hayvan sayısını hem de toksin kullanım miktarını azaltmak için sentetik peptit immünojenlerinin kullanılmasının gerekliliğini ortaya koymaktadır.

Anahtar Kelimeler: Antikor üretimi, Botulinum nörotoksin A, botulizm, sentetik peptitler, toksin tespiti. 


\section{Introduction}

The native Botulinum neurotoxin $(150 \mathrm{kDa})$ is produced by Clostridium botulinum as a single polypeptide chain and has no neurotoxic effect. The neurotoxic effect of the toxin occurs after a two-stage modification of the native protein structure. First, the single-chain structure is cleaved between the 448 and 449 amino acids(aa) forming a two-chain structure consisting of a light chain $(\mathrm{L}, 50 \mathrm{kDa})$ and a heavy chain $(\mathrm{H}, 100 \mathrm{kDa})$. At this stage, the light and heavy chains are connected by a disulfide bond. ${ }^{1-4}$ Then, in the nerve cells, the light and heavy chains dissociate from each other by the cleavage of the disulfide bond.

BoNTs have three domains and each plays different roles during toxin's mechanism neuroparalytic action. The heavy chain consists of two domains; the receptor-binding domain (HC, 871-1296 aa) that enables the toxin to bind to the receptors located on the nerve cells surface. The translocation domain ( $\mathrm{HN}, 450-870$ aa) mediates the light chain of the toxin to enter into the cytoplasm of nerve cells. After the translocation into the cytosol, the light chain (LC, 1-434 aa) shows a neurotoxic effect. ${ }^{5}$ The light chains of different BoNTs cleave different synaptic proteins, such as the synaptosomal-associated protein 2 (SNAP-25) and the synaptobrevin-2, 6,7 which results in blocking of neurotransmitter release in the neuromuscular junction causing the flaccid paralysis of the muscles. ${ }^{8-10}$

BoNTs have seven serotypes (A-G) with similar characteristics. Botulism in humans is mainly caused by serotypes A, B, and E and rarely by F. BoNTs are the most potent neurotoxins ever known. In addition to causing botulism, BoNTs have been the subject of many studies due to their high potential for toxin use for bioterrorism ${ }^{11}$. Laboratory personnel are exposed to the toxin, both in research studies and in studies for the diagnosis of the disease, which poses a vital risk. The lethal dose of the toxin in humans is not implicitly known. According to experiments done in primates, the lethal dose for a $70 \mathrm{~kg}$ human is estimated to be between $0.09-0.15 \mu \mathrm{g}$ intravenously or intramuscularly and $70 \mu \mathrm{g}$ when taken orally. ${ }^{11,12}$

The mouse bioassay is accepted as the gold standard ${ }^{13}$ in the detection of the toxin, but it is a labor-intensive and timeconsuming assay (up to 4 days) which results in many sacrifices of experimental animals. In case of a possible toxification due to BoNT A, delay in detection of toxin might result in death because the treatment couldn't be started before detection of the toxin. BoNT A, which is classified in category A by CDC in the list of biological agents, is a challenging molecule for both laboratory analysis and antibody development studies due to its high toxicity. ${ }^{14}$ The development of anti-BoNT antibodies includes time-consuming and labor-intensive steps such as the production of toxin from bacteria and the conversion of toxin into toxoid. ${ }^{15}$ Most diagnostic systems have been developed to recognize the toxin itself rather than the bacteria and still rapid and high sensitivity tests are needed to be developed to detect toxins as early as possible during intoxication. ${ }^{16,17}$ Antibodies have not only revolutionized the scientific world since their discovery, but have led the race for sensitivity, specificity, and rapid diagnosis with DNAbased diagnostic systems in recent decades. ${ }^{18}$ Newly released high throughput systems such as chemiluminescent immunoassay (CLIA), electrochemiluminescence (ECL), time-resolved fluorescence (TRF) and fluorescenceactivated cell sorting (FACS) also show that antibodies will always be a headliner of cutting-edge technologies. ${ }^{19}$ Using peptides instead of intact native antigens or toxins for the development of antibodies used in these systems will eliminate the obstacles experienced with native antigens which are difficult to purify and produce in large amounts. ${ }^{20}$ The studies with synthetic peptides in antibody development so far show that the developed anti-peptide antibodies are also known to cross-react with the native intact protein at high frequencies. In addition, the use of synthetic peptides in cases where the protein from which the antibodies will be raised is toxic provides both high safety and high availability. ${ }^{21,22}$

In this study, as described by Hancock and Orielly ${ }^{22}$ synthetic peptides were used as immunogens instead of using the native intact toxin itself. Synthetic peptides were designed from the three domains of the BoNT A serotype. These peptides were used for mice immunizations with the aim of getting an immune response. When the immune response against peptides was examined it was shown that a high anti-BoNT A antibody response was obtained at the picogram levels. These high-affinity antibodies might allow the decrease of the toxin used in the development of diagnostic systems, decreasing by this way the potential risk of the laboratory staff exposure. Working with BoNTs requires qualified laboratory infrastructure, as well as exposure to the toxin in long-term experiments, creates dangers for laboratory staff on occupational health and safety. Studies with peptides have advantages such as ease of use of peptides and reduction of toxin exposure compared to studies with toxins.

\section{Methods}

\section{Materials}

Pure type BoNT A $(0.81 \mu \mathrm{g} / \mathrm{mL})$, produced in culture and purified as a $150 \mathrm{kDa}$ holotoxin, was provided from the General Directorate of Public Health (HSGM) Ankara, Turkey, and stored at $-20^{\circ} \mathrm{C}$. All chemicals were purchased from Sigma-Aldrich Chemie $\mathrm{GmbH}$ (Taufkirchen, Germany) unless otherwise stated. All peptides (P1, P2, and P3) were purchased from GenScript USA Inc. (NJ, USA) in conjugated to bovine serum albumin (BSA), keyhole limpet hemocyanin $(\mathrm{KLH})$, or ovalbumin (OVA) forms. All gel electrophoresis equipment, Trans-Blot ${ }^{\mathbb{R}}$ Turbo $^{\mathrm{TM}}$ Transfer Starter System and power supply (PowerPac Universal Power Supply \#1645070) were purchased from BioRAD Laboratories (Hercules, CA), ELISA reader (Synergy HTX, Multimode Reader), and ELISA washer (EL496 Washer Dispenser) were purchased from Bio-TEK Instruments, Inc., (Winooski, VT).

\section{Peptide Design and Synthesis}

The following protein sequences and crystal structures were downloaded from RCSB PDB ${ }^{23}$; Botulinum Type A (UniProtKB/Swiss-Prot: P0DPI1), Botulinum Type B (UniProtKB/Swiss-Prot: P10844), Type E (UniProtKB/Swiss-Prot: Q00496) and Type E (UniProtKB/Swiss-Prot: A7GBG3). Firstly, candidate peptides were selected for the light chain, receptor binding domain, and translocation domain of BoNT A from the literature ${ }^{24}$. Using the epitope estimation tools at the Immune Epitope Database (IEDB) ${ }^{25}$ (https://www.iedb.org/) and Discovery Studio 4.0 Visualizer software (downloaded from https://discover.3ds.com/discovery-studio-visualizerdownload), the sequences of the selected epitopes were observed on the crystal structure of BoNT A with PDB 
code3BTA. And linear epitopes displayed on the surface of the toxin were selected as peptides (Table 1). The peptides were purchased from Gen Script in a conjugated form with $>85 \%$ purity.

Table 1. Candidate Peptides As Immunogens

\begin{tabular}{l|ll}
\hline Region & Aa Sequence & Location \\
\hline \multirow{2}{*}{$\mathrm{L}$} & GQMQPVKAFKIHNKIWVIPERDTFTN & $28-53$ \\
& AVTLAHELIHAGHR & $218-231$ \\
& ALNDLCIKVNNWDLFFSPSEDNFTN & $449-473$ \\
$\mathrm{HN}$ & FFSPSEDNFTNDLNKGEEI & $463-481$ \\
& KGEEITSDTNIEAAEENIS & $477-495$ \\
& DYVKKVNKATEAAMFLGWV & $589-607$ \\
& GICNKCKMNLQDNNGNDIGFIGFHQ & $1230-1254$ \\
& NKCKMNLQDNNGNDIGFIG & $1233-1251$ \\
& IGFIGFHQFNNIAKLVASN & $1247-1265$ \\
& LVASNWYNRQIERSSRTLG & $1261-1279$ \\
& SRTLGCSWEFIPVDDGWGERPL & $1275-1296$ \\
\hline
\end{tabular}

\begin{abstract}
Animal Testing
In current studies, 15 male BALB/c mice, eight weeks old with the body mass of $(26 \pm 2) \mathrm{g}$, were used. Mice were house in groups of five in standard animal room conditions with unlimited access to food and water. The temperature and relative humidity were maintained at $(21 \pm 1){ }^{\circ} \mathrm{C}$ and 50 $60 \%$ respectively. Mice were dosed with each peptide of 75 $\mu$ (in $200 \mu \mathrm{L}$ PBS) per mouse by the intraperitoneal (IP) route. After $12 \mathrm{~h}$ of the last feeding, firstly xylazine at dose $100-200-\mathrm{mg} / \mathrm{kg}$ was given by IP route, and then all mice were sacrificed by cervical dislocation. The animal experiments described in the current study were approved by the Institutional Animal Care and Use Committee (HADYEK) of TUBITAK Marmara Research Center, Genetic Engineering and Biotechnology Institute (TUBITAK MRC GEBI) (Protocol Number: 16563500-111103) performed in compliance with the recommendations in the Guide for the Care and Use of Laboratory Animals.
\end{abstract}

\section{Immunizations and Screening}

Mice were immunized 5 times at 2-week intervals, with the $75 \mu \mathrm{g}$ of BSA-conjugated form of the peptides given in Table 2 in $200 \mu \mathrm{l}$ PBS by IP route. In the first dose of injection, complete Freund's adjuvant was used. The subsequent doses were prepared within incomplete Freund's adjuvant. The mice were bled on day 10 after each immunization and sera were collected by centrifugation. Anti-peptide antibody titers were evaluated by indirect ELISA $^{26}$ with 1000-fold diluted serum in phosphatebuffered saline (PBS: $10 \mathrm{mM}$ K2HPO4, 10mM KH2PO4, $0.15 \mathrm{~mol} / \mathrm{L} \mathrm{NaCl}, \mathrm{pH}=7.2$ ) with $100 \mathrm{ng} \mathrm{P} 1-\mathrm{KLH}, \mathrm{P} 2-\mathrm{KLH}$, and P3-OVA coated plates (Nunc 96 well MicroWell ${ }^{\text {TM }}$ MaxiSorp ${ }^{\text {TM}}$ ). The Alkaline Phosphatase (AP) labeled polyvalent antibody was used as the detection antibody. 4-nitrophenyl phosphate di-tris salt for AP substrate was prepared in AP buffer at a concentration of $1 \mathrm{mg} / \mathrm{mL}$. The plate was read at $405 \mathrm{~nm}$ absorbance at 30 min and $1 \mathrm{~h}$ of incubation and the background (wells with sera of the non-immunized mouse) was subtracted.

\section{Indirect ELISA}

To determine the interaction of native BoNT A with antipeptide immune response indirect ELISA $^{26}$ was used. The concentration range of BoNT A from $10^{1}$ to $10^{7}$ was coated to ELISA plates. The coating of the plate was carried out at $4{ }^{\circ} \mathrm{C}$ overnight. Some wells were incubated with PBS as negative control. 1.000, and 5000 fold diluted mice sera was dispensed to the designated wells. The non-immunized mouse sera or PBS was used as the negative controls. 2.000 fold diluted AP-conjugated rabbit anti-mouse polyvalent antibody (Sigma-Aldrich Chemie GmbH, Taufkirchen, Germany) was used as the secondary antibody. 4nitrophenyl phosphate prepared in the substrate buffer (1 $\mathrm{mM} \mathrm{ZnCl} 2,1 \mathrm{mM} \mathrm{MgCl} 2,0.1 \mathrm{M}$ glycine $\mathrm{pH} 10.4)$ was used as AP substrate. Absorbance at $405 \mathrm{~nm}$ was measured with a micro plate reader.

\section{Electrophoresis}

SDS gel and Western blot studies were performed to indicate that the toxin we used was intact and could interact with anti-BoNT A antibodies, respectively.

All gel electrophoresis equipment, transblot device, and acrylamide purchased from BioRAD Laboratories Inc (Hercules, CA, USA); PVDF membrane from Thermo Scientific (Madison, WI, USA); $\mathrm{HCl}, \mathrm{MeOH}, \mathrm{EtOH}$, acetic acid, and formaldehyde from Merck KgaA (Darmstadt, Germany). $10 \mathrm{ng}$ BoNT A was denatured with $1 \mathrm{mM}$ DTT for $10 \mathrm{~min}$ at $95^{\circ} \mathrm{C}$ and loaded into wells for silver staining. After the samples were run for $1 \mathrm{~h}$ at $100 \mathrm{~V}$ and $1 \mathrm{~h}$ at 150 Vat $10 \%$ SDS PAGE, the Silver Staining protocol was applied. Firstly, the gel was incubated with fixation buffer $(50 \% \mathrm{MeOH}, \quad 12 \%$ Acetic Acid, $0.5 \mathrm{~mL} 37$ $\%$ Formaldehyde) for $1 \mathrm{~h}$ and then washed with washing buffer $\left(50 \% \mathrm{EtOH}, 50 \% \mathrm{dH}_{2} \mathrm{O}\right)$ for $1 \mathrm{~h}$. After washing, the gel was treated with pretreatment buffer $\left(0.2 \mathrm{~g} \mathrm{Na}_{2} \mathrm{~S}_{2} \mathrm{O}_{3} .5 \mathrm{H}_{2} \mathrm{O}\right)$ for $1 \mathrm{~min}$. The gel band washed with distilled water was left to incubate for $20 \mathrm{~min}$ with band fixation buffer $(2 \mathrm{~g} / \mathrm{L}$ $\mathrm{AgNO}_{3}$, and $0.75 \mathrm{~mL} \mathrm{37 \%} \mathrm{Formaldehyde).} \mathrm{After} \mathrm{incubation,}$ the gel was washed again with $\mathrm{dH}_{2} \mathrm{O}$ and waited until the bands became evident in the development buffer $(60 \mathrm{~g} / \mathrm{L}$ $\mathrm{Na}_{2} \mathrm{CO}_{3}, 4 \mathrm{mg} / \mathrm{L} \mathrm{Na} \mathrm{S}_{2} \mathrm{O}_{3}$, and $0.5 \mathrm{~mL} 37 \%$ Formaldehyde). After the bands were displayed, the reaction was stopped with stop buffer $(50 \% \mathrm{MeOH}, 12 \%$ Acetic acid, 38\% $\left.\mathrm{dH}_{2} \mathrm{O}\right)$ and washed with the last wash buffer $(50 \% \mathrm{MeOH}$, $50 \% \mathrm{dH}_{2} \mathrm{O}$ ). 
For western blotting; $0.8 \mathrm{ng}$ BoNT A was electrophoresed on SDS-PAGE as described above in the presence of $1 \mathrm{mM}$ DTT. The gel was blotted onto a PVDF membrane via BioRAD Trans-Blot Turbo Transfer System for $30 \mathrm{~min}$. The membrane was blocked with $20 \mathrm{ml} 1 \%$ milk powder to prevent non-specific binding. After blocking, the membrane was washed three times with $20 \mathrm{~mL}$ TBS-T $(20 \mathrm{mM}$ Tris, $0.9 \% \mathrm{NaCl}, 0.05 \%$ Tween-20, $\mathrm{pH}=7.4)$ and then incubated with anti-BoNT A rabbit pAb (\#NB110-17098, Novus appear on the gel (approximately $5 \mathrm{~min}$ ) the reaction was stopped by washing the membrane with $\mathrm{dH}_{2} \mathrm{O}$.

\section{Statistical Analysis}

In this study, all experiments were performed as three repeats. The data were analyzed using the ANOVA test via using GraphPad Prism 5 (San Diego, CA) and results with $p<0.05$ were considered statistically significant. The LOD, LOQ, and $r$ values were calculated via Microsoft Excel data analysis tools.

\section{Results}

\section{Peptide Design and Synthesis}

Within the scope of the study, immunogenic peptides from BoNT A were designed. All three BoNT A domains contain immunogenic regions. ${ }^{25}$ Therefore, possible peptide candidates were selected for each of them. B cell epitopes were selected as synthetic peptide candidates due to the fact that B cells are the main cells of antibody production while $\mathrm{T}$ cells are responsible for cell-based toxicity and complement activation. However B cell epitopes can be continuous or discontinuous and generally discontinuous ones dominate most antigenic epitope families ${ }^{27}$. For this reason, Linear B cell epitopes were selected.

The steps followed in the design of the peptides are given below.
Biologicals LLC, CO, USA) in 1:500 ratio in TBS (TRISbuffered saline). The membrane was washed again with TBS-T three times and this time incubated for $1 \mathrm{~h}$ at room temperature with an AP-labeled anti-Rabbit IgG secondary antibody in a ratio of 1:5000. The membrane was then washed with TBS-T and incubated with the substrate solution (1 tablet of 5-bromo-4-chloro-3-indolyl-phosphate/ nitro blue tetrazolium (BCIP/NBT) substrate in $10 \mathrm{ml}$ $\mathrm{dH}_{2} \mathrm{O}$ ). Until the bands 1- Candidate peptides were selected from epitopes listed in the literature ${ }^{24}$ (Table 1).

2- The sequences of the epitopes designed using the epitope estimation tools at IEDB were compared with the selected epitopes as below;

i. "B cell Epitope Prediction Tools" selected from IEDB

ii. "Prediction of linear epitopes from protein sequence" was chosen as the algorithm and Bepipred Linear Epitope Prediction 2.0 was chosen as the method. For BoNT A, UniProtKB - P0DPI1 reference sequence accession number was used, FASTAs were entered separately for each domain of BoNT A and the candidates having the most likely linear epitope regions from these were recorded (data not shown); iii. The sequences of the candidate peptides were visualized on the crystal structure of BoNT A (UniProtKB - P0DPI1) with Discovery Studio 4.0 Visualizer. For $\mathrm{L}$ sequence between 45-75, for HN 470-495 and for HC 1230-1242 were found to be the most visible and continuous epitopes on the surface of the protein (Fig.1).

The optimal peptide length for immunization is accepted as 10-20 aa residues so peptides shown in Table 2 were selected for synthesis. Selected peptides were purchased in a conjugated form (to BSA, KLH, and OVA proteins) with $>85 \%$ purity from Gen Script and mice immunizations were done with those conjugated to BSA.

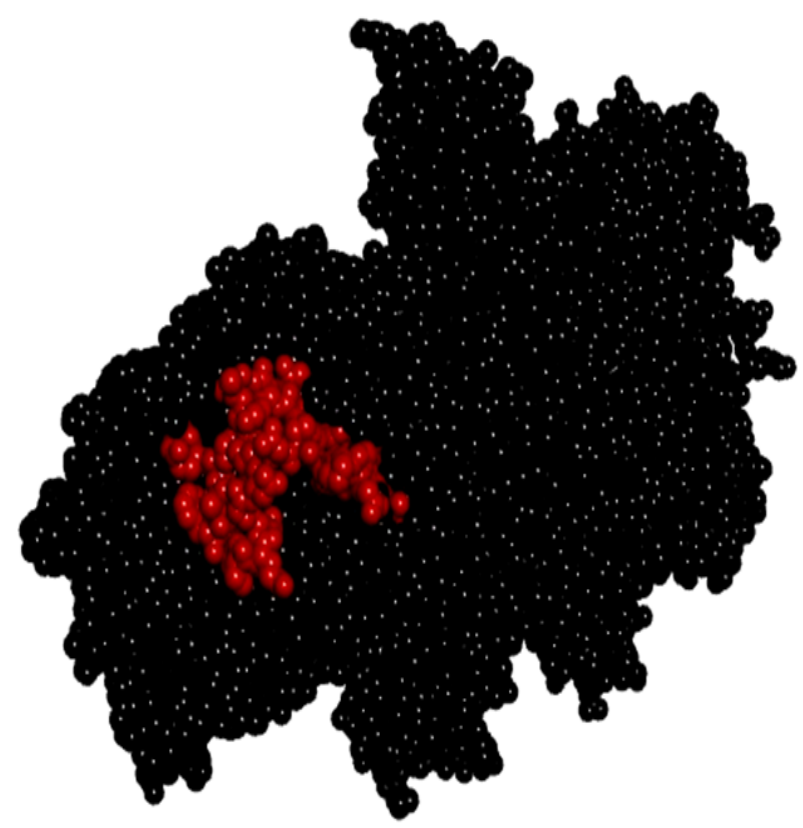

Fig 1. The Three-Dimensional Model of Botulinum Neurotoxin A Epitope Selection (Blue; L 45-75, Green; HN 470-495aa, Red; HC 1230-1242) 
Table 2. Amino Acid Sequence of Selected Peptides

\begin{tabular}{l|llll}
\hline Peptide & Region & Sequence & Immunogen Form & Length (aa) \\
\hline P1 & L & PEEGDLNPPPEAKQ & C-PEEGDLNPPPEAKQ-BSA & $54-67(15$ aa) \\
P2 & HN & NDLNKGEEITSDTNC & NDLNKGEEITSDTNC-C-BSA & $473-487(15 \mathrm{aa})$ \\
P3 & HC & GITNKCKMNLQDN & Q-GITNKCKMNLQD- BSA & $1229-1241(13 \mathrm{aa})$ \\
\hline
\end{tabular}

\section{Peptide Immunizations and Antibody Response}

In order to detect the presence of anti-peptide antibodies in mice sera, indirect ELISA was performed. Starting from the second immunization, mice sera were taken on the tenth day after each immunization and (Fig 2), the presence of antipeptide antibodies were monitored for each peptide by measuring the absorbance of each well at a $\lambda$ value of 405 nm using a Bio-Tek Synergy HTX, Multimode Reader) (Bio-Tek Instruments, Inc., Winooski, VT). It was observed that the absorbance values corresponding to the number of antibodies in the mice sera peaked after the 4th immunization.

For each antigen four mice were used and an average of their responses was given in Fig.2. [ $p<0.0001]$. All data were normalized to immune response data of the nonimmunized mice. For coating ELISA plates P1-KLH conjugate used for $\mathrm{P} 1, \mathrm{P} 2-\mathrm{KLH}$ conjugate for $\mathrm{P} 2$, and $\mathrm{P} 3-$ OVA conjugated for $\mathrm{P} 3$ were coated for immune response control. Since the immunizations were performed with peptides conjugated to BSA, the peptides to be used in ELISA studies were selected as in conjugated form to KLH in order to eliminate the immune response developed against BSA. Although there was no problem with the KLH conjugated form of P1 and P2, the KLH conjugated form of $\mathrm{P} 3$ precipitated and could not be used in the homogenized form. For this reason, P3 was ordered in and used as conjugated to OVA.

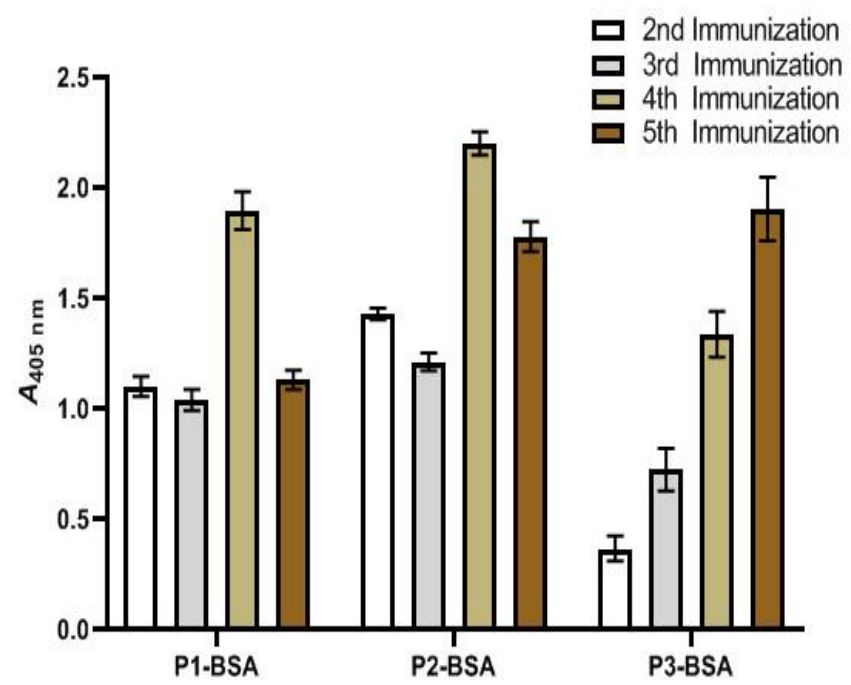

Fig 2. Antibody responses of mice (with $1 / 1000$ serum dilution) immunized with $75 \mu \mathrm{g}$ /mouse P1-BSA, P2-BSA, and P3-BSA respectively. For each column, the mean data of the 4 immunized mice was calculated and normalized to immune response data of the non-immunized mice. Error bars represent the mean with $\pm \mathrm{SD}$ values of triplicate wells.

\section{Demonstration of BoNT A}

BoNT A obtained from HSGM was demonstrated with silver staining and western blotting (Fig 3). For silver staining $10 \mathrm{ng}$ BoNT A which was denatured for $10 \mathrm{~min}$ at $95^{\circ} \mathrm{C}$ in the presence of $1 \mathrm{mM}$ DTT (Lane 2) was used while for western blotting $0.8 \mathrm{ng}$ BoNT A containing samples which were denatured at $95^{\circ} \mathrm{C}$ for $10 \mathrm{~min}$ in the presence of $1 \mathrm{mM}$ DTT were used. In western blotting after transferring proteins into PVDF membrane, incubation was performed with anti-Rabbit pAb (1/500).

These data show that toxin could be demonstrated by silver staining and proved to be able to bind to a polyclonal commercial antibody by western blot. The toxin obtained from HSGM, was shown to be BoNT A complex with nontoxic neurotoxin-associated proteins because both in silver staining and western blotting too many bands were observed other than the 50,100 , and $150 \mathrm{kDa}$ bands of the holotoxin itself.

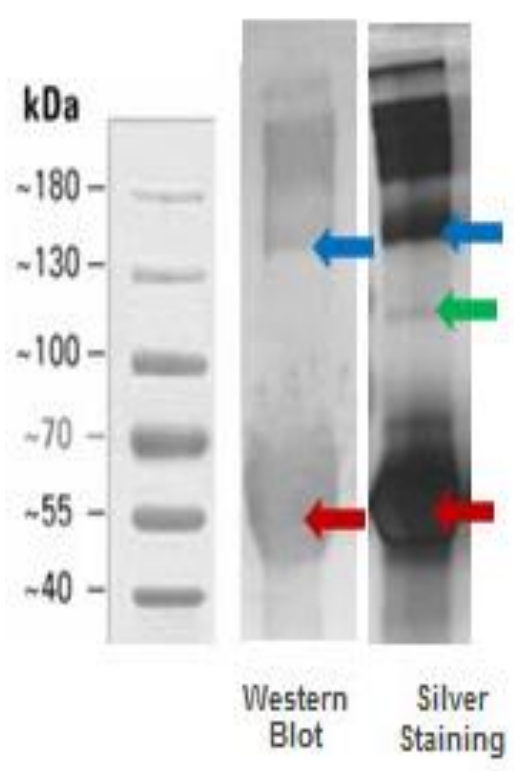

Fig 3. Antibody binding by Western blotting following SDS-PAGE. $1^{\text {st }}$ line; Marker. $2^{\text {nd }}$ line; $0.8 \mathrm{ng}$ BoNT A was electrophoresed on \%10 SDS-gels in the presence of $1 \mathrm{mM}$ DTT and membrane probed with 1/500 TBS diluted antiBoNT A rabbit pAb. $3^{\text {rd }}$ line; $10 \mathrm{ng}$ BoNT A detected by silver staining. Red, green, and blue arrows represent 50 $\mathrm{kDa}$ of BoNT A (LC), $100 \mathrm{kDa}$ of BoNT A (HC), $150 \mathrm{kDa}$ of the holotoxin, respectively. 


\section{Native BoNT A Detection with Anti-Peptide Antibodies}

In order to answer the question of at what concentration anti-peptide antibodies that were produced against BoNT A epitopic regions recognize native BoNT A and ELISA protocol in which BoNT A concentration was tittered against anti-P2 mice sera, was performed. Plates were coated with the BoNT A $(0.81 \mu \mathrm{g} / \mathrm{mL})$ which is diluted by serial dilution from $10^{1}$ to $10^{7}$ times. After the $5^{\text {th }}$ immunization, sera of two mice which were randomly selected from the P2 immunization group (diluted 1/1000) and PBS were dispensed into ELISA wells coated with the toxin. According to the optical density (OD) measurements, the limit of detection (LOD) of anti-P2 antibodies was calculated as $17,06 \mathrm{pg} / \mathrm{mL}$, the limit of quantification (LOQ) as $51,71 \mathrm{pg} / \mathrm{mL}$ and the correlation coefficient (r) of the graph was 0,57 (means moderate correlation) (Fig. 4).

After determining the concentration at which mice sera recognize the toxin, ELISA was done to measure the antibody responses, originally developed against P1-BSA, P2-BSA, and P3-BSA (Fig. 5). The 5th immunization sera of mice immunized with $\mathrm{P} 1, \mathrm{P} 2$, and $\mathrm{P} 3$ were diluted by $1 / 1000$ were added to the ELISA plates coated with $0.81 \cdot 10^{-}$ ${ }^{3} \mu \mathrm{g} / \mathrm{mL}, 0.81 \cdot 10^{-4} \mu \mathrm{g} / \mathrm{mL}$ BoNT A and PBS, respectively. The anti-peptide antibodies generated by using $\mathrm{P} 1, \mathrm{P} 2$, and P3 were shown to cross-react with native intact BoNT A at the concentration of $0.81 \cdot 10^{-4} \mu \mathrm{g} / \mathrm{mL}$.

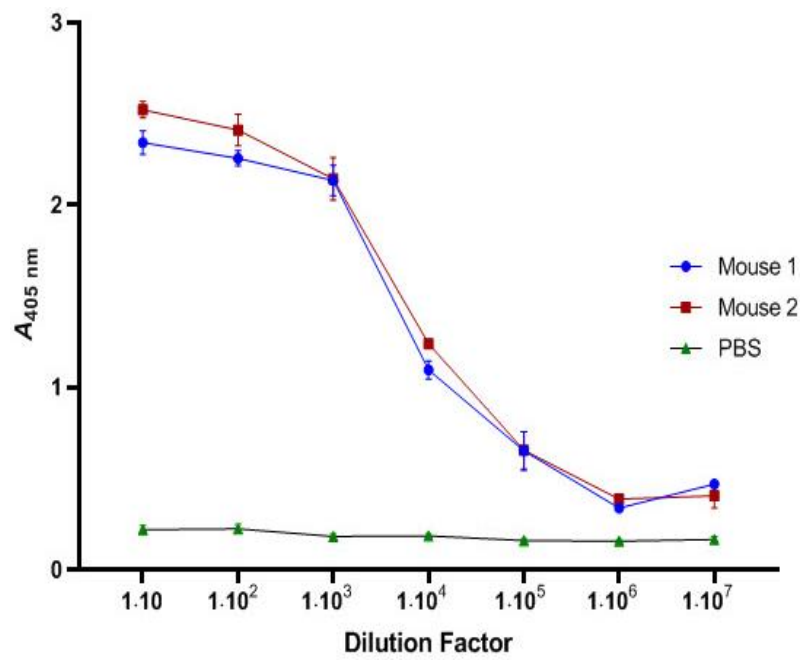

Fig 4. BoNT A $(0.81 \mu \mathrm{g} / \mathrm{mL})$ was tittered against anti-P2 antibodies. ELISA plates were coated with BoNT A which was serially diluted with PBS up to $10^{7}$ fold. 2 randomly selected P2-BSA immunized mice sera (1/1000 diluted) and PBS (as negative control) were dispensed into BoNT A coated ELISA plates $(n=3 \pm S D)$. LOD, LOQ, and $r$ were calculated as $17.06 \mathrm{pg} / \mathrm{mL}, \quad 51.7 \mathrm{pg} / \mathrm{mL}$, and 0.57 respectively.

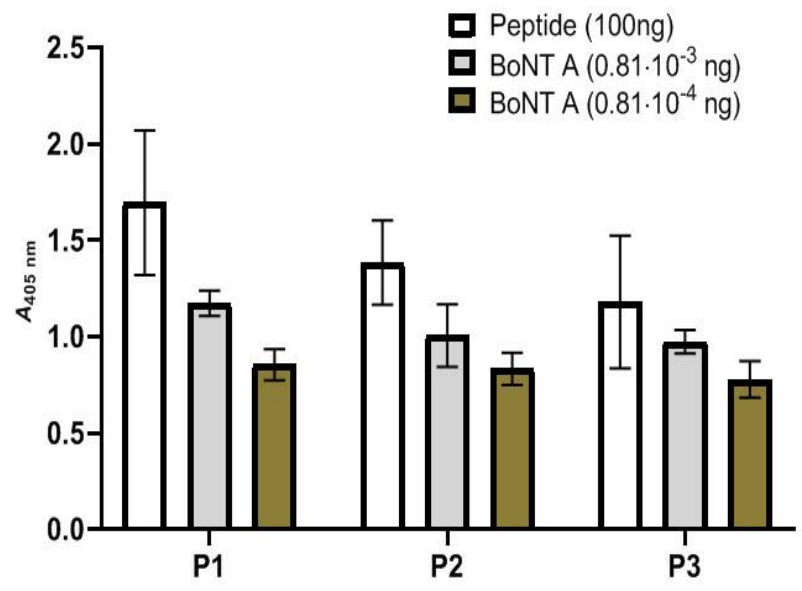

Fig 5. Comparison of Antibody Responses of mice (with $1 / 1000$ serum dilution) immunized with $75 \mu \mathrm{g} /$ mouse P1, $\mathrm{P} 2$, and $\mathrm{P} 3$ peptides respectively against BoNT A. $[p<0.0001]$. For each column, the mean data of the 4 immunized mice was calculated and normalized to immune response data of the non-immunized mice. Error bars represent the mean with \pm SD values of triplicate wells.

\section{Discussion}

The main goal of this study was to raise antibodies against peptides specific to BoNT A and to evaluate the capability of cross-reactivity of those raised antibodies against the native toxin. First of all, some rules were taken into consideration while designing the peptide. The length of the peptide is very important for high immunogenicity. The optimal peptide length for immunization is accepted as 10-20 aa residues because peptides shorter than 7 aa residues are insufficient to induce an immune response and peptides longer than 20 aa residues cannot reflect the original conformation in the intact protein by adopting a new 3D conformational structure alone. ${ }^{22}$ Even if they are within the optimal length limits, peptides are still poor immunogens without a carrier protein. In order to an induce immune response, carrier proteins provide MHC Class II or T-cell receptor epitopes while peptides serve as B cell determinants. ${ }^{22}$ Based on this information since P1 and P2 were longer than 20 aa they were further shortened and peptides shown in Table 2 were selected for synthesis. When the FASTA's of other Botulinum serotypes causing botulism in humans such as B, E, and F (UniProt ID's are P10844, Q00496, A7GBG3 respectively) were examined, it was seen that they do not contain the selected peptide sequences. Selected peptides were purchased in a conjugated form (to BSA, KLH, and OVA proteins) with $>85 \%$ purity from Gen Script and mice immunizations were done with those conjugated to BSA.

Free amino, carboxylic acid, or sulfhydryl groups are needed to conjugate the carrier proteins to peptides. Normally conjugates can be attached to the N-terminus and C-terminus of the peptide or to the cysteine $(\mathrm{C})$ residues if present. The presence of amino acids containing $\mathrm{NH} 2$ (lysine, asparagine) and $\mathrm{COOH}$ (aspartic acid, glutamic acid) groups in the side chain or the presence of more than one $\mathrm{C}$ in the peptide sequence may lead to random conjugation location and disruption in the $3 \mathrm{D}$ structure of the peptide. ${ }^{28}$ Neither the $\mathrm{N}$-terminal nor the C-terminal conjugation was considered suitable for these peptides, as they contain the $\mathrm{K}, \mathrm{D}$, and $\mathrm{E}$ residues (Table 2.). By adding the $\mathrm{C}$ residue to the $\mathrm{N}$-terminus of $\mathrm{P} 1$ and the $\mathrm{C}$-terminal of $\mathrm{P} 2$, conjugation was performed in these peptides via the $\mathrm{C}$ residue in order not to disrupt the $3 \mathrm{D}$ structure of the peptides. On the other hand, since $\mathrm{P} 3$ contains a $\mathrm{D}$ residue close to the $\mathrm{C}$ terminal, it was decided to make a $\mathrm{C}$ terminal conjugation. In this case, it was ensured that the conjugate would be at the C-terminus, regardless of whether the conjugate was added to the $\mathrm{COOH}$ in the side chain of $\mathrm{D}$ or the $\mathrm{C}$ terminal $\mathrm{COOH}$.

Obtaining similar levels of antibody titer from the 3 peptides indicates that each of the selected synthetic peptides has been successful in inducing an immune response. This result has led to the belief that when used in sandwich systems, monoclonal or polyclonal antibodies against these peptides, which are selected from three different and distant regions of BoNT A in 3D conformation, will increase the sensitivity and specificity of the detection system. 
Then the interaction between anti-peptide sera and native BoNT A was examined via ELISA and it was found that the neurotoxin is recognized at picogram levels in $\mathrm{mL}$ by the response developed against peptides. These data indicate that antibodies raised against synthetic peptides were able to bind to native BoNT A at picogram levels in $\mathrm{mL}$. This result was previously reached by other groups ${ }^{29-31}$ using the toxin, toxoid form of BoNT A in its native form or by using much longer sequences corresponding to the protein domains of BoNT A as synthetic peptide. ${ }^{32}$

In this study, we have shown for the first time that it is possible for antibodies raised against small epitopic peptides (15 aa long) designed by using bioinformatics tools to be bound to native BoNT A with high affinity. As previously shown by other groups ${ }^{29-31}$, it is possible to raise highaffinity $\mathrm{mAbs}$ against botulinum neurotoxin A by using the toxoid form of the native botulinum neurotoxin itself, using a large recombinant form of the toxin. ${ }^{32}$

The use of a protein as a whole or a large part in antibody development studies results in the generating of antibodies against a large number of epitopes found on the protein. The use of synthetic epitopic peptides in polyclonal antibody development studies both leads to the generating of highaffinity antibodies against a specific epitope of the protein and to an increase in the titer of the developed antibody. ${ }^{33}$

With the results obtained as a result of the study, it was observed that the use of synthetic peptides specially designed for B cell epitopes as immunogens by using bioinformatic tools led to an increase in both antibody titers and the affinity of the developed antibodies.

There are difficulties in the manipulation of toxins such as the requirement of a serious laboratory infrastructure (such as BSL-3), and the necessity of high number of experimental animal usage in these studies. So, it has been evaluated that usage of peptides that are designed using bioinformatics tools in this way not only for BoNT serotypes but also for all other toxic molecules will be a great convenience for diagnostic tests and other R\&D studies.

The reason why monoclonal antibody $(\mathrm{mAb})$ could not be obtained is thought to be due to the fact that immunization studies with synthetic peptides are more suitable for raising polyclonal antibodies (pAb) rather than monoclonal ones. Actually, synthetic peptides present some problems when they are presented as antigens together with carrier proteins. Especially when it is desired to develop mAbs with such antigens, the antibody response to the carrier protein may mask the weaker anti-peptide response, resulting in the development or even loss of very few peptide-specific hybridomas. $^{22}$

In addition to this, pAbs or mAbs have some advantages over each other. During development, pAbs produce faster results, while mAb development takes longer than one year, hence requiring more time and expense. Because mAbs are produced against a single epitope, they are homogeneous and consistent. However, any alteration in the epitope recognized by $\mathrm{mAb}$ (ie due to the glycosylation or denaturation) can markedly reduce the affinity of the mAb. On the other hand, pAbs are heterogeneous and recognize multiple antigenic epitopes. They are less affected by changes in the structure of an epitope. Besides, small changes in $\mathrm{pH}$ and salt concentration can dramatically affect mAbs, whereas pAbs are more stable and resilient.
pAbs present a combination of antibodies, each produced by $\mathrm{B}$ cells against a particular epitope, and therefore offer unique specificity over mAbs. On the other hand, mAbs have a higher concentration and purity level of the antibody produced by a specific B cell.

The major advantage of mAbs is that they offer an almost unlimited source of antibodies and are stable once the desired hybridoma has been raised. On the other hand, pAbs differ between immunized animals and their avidity may change during the harvesting period. The amount of pAbs obtained is limited by the blood volume and lifespan of the vaccinated animal. ${ }^{34}$ In summary, pAbs and mAbs offer different advantages according to their intended purpose.

\section{Limitations}

The cross-reaction of the developed anti-peptide antibodies with other BoNT serotypes could also be examined within the scope of the study. Thus, how specific these anti-peptide antibodies were would be evaluated. However, although these studies were planned within the scope of the project, they could not be carried out because BoNT serotypes were difficult to produce and their suppliance from abroad was subject to regulations or even impossible.

\section{Conclusion}

In this study, mouse pAbs were developed against BoNT A, which is the most potent toxin known in nature. Within the scope of this study, synthetic peptides, which were selected to be specific to immunogenic regions on the surface of 150 $\mathrm{kDa}$ protein, were used as antigens. Antibodies raised in mice against the three different peptides have been shown to cross-react with the native intact BoNT A in picogram levels. In this way, rapid recognition kits against toxic antigens can be produced by producing antibodies.

In conclusion, the current study shows that very small synthetic peptides which are designed bioinformatics tools are at least as effective as the native toxin or the toxoid itself for raising high-affinity antibodies.

\section{Conflict of Interest}

The authors declare that they have no conflict of interest.

\section{Compliance with Ethical Statement}

Ethical approval was obtained from the Institutional Animal Care and Use Committee (HADYEK) of TUBITAK MRC GEBI with 16563500-111-103 ethical number.

\section{Author Contributions}

MI: Peptide Design; MI, ZB: Design and Performance of Experiments; MI, SO; Project Development, MI, SO; Analysis and Interpretation of Data, MI; Literature Search; MI, NC and SO: Manuscript writing.

\section{Funding}

This research was funded by TUBITAK "1009 Rabbit Sera" Project (117H001) and performed at Genetic Engineering and Biotechnology Institute of TUBITAK Marmara Research Center.

\section{Acknowledgement}

We are grateful to Prof. Dr. Selçuk Kılıç and Public Health Institution of Turkey for providing BoNT A. 


\section{References}

1. Bigalke $\mathrm{H}$, Rummel A. Medical aspects of toxin weapons. Toxicology. 2005;214(3):210-220. doi:10.1016/j.tox.2005.06.015

2. Middlebrook JL, Franz DR. Botulinum Toxins. Med. Aspects of Chem. and Biol. Warfare. 1997; 603-76.

3. White SM. Chemical and biological weapons. Implications for anaesthesia and intensive care. $B r \quad J$ Anaesth. 2002;89(2):306-324. doi:10.1093/bja/aef168

4. Patocka J, Splino M. Botulinum Toxin: From Poison to Medicinal Agent. The ASA Newsletter. 2002; 88: 14-24.

5. Gu S, Rumpel S, Zhou J, et al. Botulinum neurotoxin is shielded by NTNHA in an interlocked complex. Science. 2012;335(6071):977-981. doi:10.1126/science. 1214270

6. Schiavo G, Benfenati F, Poulain B, et al. Tetanus and botulinum-B neurotoxins block neurotransmitter release by proteolytic cleavage of synaptobrevin. Nature. 1992;359(6398):832-835. doi:10.1038/359832a0

7. Blasi J, Chapman ER, Link E, et al. Botulinum neurotoxin A selectively cleaves the synaptic protein SNAP-25. Nature. 1993;365(6442):160-163. doi:10.1038/365160a0

8. Simpson LL. Clinically relevant aspects of the mechanism of action of botulinum neurotoxin. Journal of Voice. 1992; 6(4); 358-364. doi:10.1016/s0892-1997(05)80034-7

9. Hong W. SNAREs and traffic [published correction appears in Biochim Biophys Acta. 2005 Jul 10;1744(3):465]. Biochem Biophys Acta. 2005;1744(2):120-144. doi:10.1016/j.bbamcr.2005.03.014

10. Elias M, Al-Saleem F, Ancharski DM, et al. Evidence that botulinum toxin receptors on epithelial cells and neuronal cells are not identical: implications for development of a nonneurotropic vaccine. J Pharmacol Exp Ther. 2011;336(3):605612. doi:10.1124/jpet.110.175018

11. Arnon SS, Schechter R, Inglesby TV, et al. Botulinum toxin as a biological weapon: medical and public health management [published correction appears in JAMA 2001 Apr 25;285(16):2081]. JAMA. 2001;285(8):1059-1070. doi:10.1001/jama.285.8.1059

12. Schantz EJ, Johnson EA. Properties and use of botulinum toxin and other microbial neurotoxins in medicine. Microbiol Rev. 1992;56(1):80-99.

13. Solomon HM, Lilly TJ. Clostridium botulinum. Bacteriological analytical manual. FDA. 2001. Available from: $\quad$ https://www.fda.gov/food/laboratory-methodsfood/bam-chapter-17-clostridium-botulinum.

14. Marks JD. Medical aspects of biologic toxins. Anesthesiol Clin North Am. 2004;22(3):509-vii. doi:10.1016/j.atc.2004.05.010

15. Keller JE. Characterization of new formalin-detoxified botulinum neurotoxin toxoids. Clin Vaccine Immunol. 2008;15(9):1374-1379. doi:10.1128/CVI.00117-08

16. Cai H, Reinisch K, Ferro-Novick S. Coats, tethers, Rabs, and SNAREs work together to mediate the intracellular destination of a transport vesicle. Dev Cell. 2007;12(5):671682. doi:10.1016/j.devcel.2007.04.005

17. Čapek P, J. Dickerson T. Correction: Čapek, P., et al. Sensing the Deadliest Toxin: Technologies for Botulinum Neurotoxin Detection.Toxins. 2010; 2(1):93-94. https://doi.org/10.3390/toxins2010093

18. Diaz-Amigo C. Antibody-Based Detection Methods: From Theory to Practice. Mol. Bio.Imm. Tech. App. For Food Chemists. 2010; 223-45.

19. Wang YF, Kobayashi M. Antibody Detection: Principles and Applications. Adv. Tech. Diag. Microbiology. 2012:53-73. doi:10.1007/978-1-4614-3970-7_4.

20. Van Regenmortel MH. Synthetic peptides versus natural antigens in immunoassay. Annales de Biologie Clinique. 1993; 51(1); 39-41.

21. Niman HL, Houghten RA, Walker LE, et al. Generation of protein-reactive antibodies by short peptides is an event of high frequency: implications for the structural basis of immune recognition. Proc Natl Acad Sci $U$ S $\quad$ A. 1983;80(16):4949-4953. doi:10.1073/pnas.80.16.4949

22. Hancock DC, OReilly NJ. Synthetic Peptides as Antigens for Antibody Production. Methods Mol Biol. 2005; 295:13-25. doi:10.1385/1-59259-873-0:013.

23. Berman HM, Westbrook J, Feng Z, et al. (2000) The Protein Data Bank Nucleic Acids Res., 28: 235-242.

24. Vita R, Mahajan S, Overton JA, et al. The Immune Epitope Database (IEDB): 2018 update. Nucleic Acids Res. 2018 Oct 24. doi: 10.1093/nar/gky1006.

25. Zarebski LM, Vaughan K, Sidney J, et al. Analysis of epitope information related to Bacillus anthracis and Clostridium botulinum. Expert Rev Vaccines. 2008;7(1):55-74. doi:10.1586/14760584.7.1.55

26. Engvall E. Enzyme immunassay ELISA and EMIT. Imm.Tech. Methods in Enzymology. 1980; 70: doi:10.1016/s0076-6879(80)70067-8.

27. Ramana J, Mehla K. Immunoinformatics and Epitope Prediction. Methods Mol Biol. 2020;2131:155-171. doi:10.1007/978-1-0716-0389-5_6

28. Grant GA. Synthetic Peptides for Production of Antibodies that Recognize Intact Proteins. Curr Protoc Mol Biol .2002; 59: 1-11

29. Chiao DJ, Wey JJ, Shyu RH,et al. Monoclonal antibody-based lateral flow assay for detection of botulinum neurotoxin type A. Hybridoma (Larchmt). 2008;27(1):31-35 doi:10.1089/hyb.2007.0550

30. Sharma SK, Ferreira JL, Eblen BS,et al. Detection of type A, $\mathrm{B}, \mathrm{E}$, and $\mathrm{F}$ Clostridium botulinum neurotoxins in foods by using an amplified enzyme-linked immunosorbent assay with digoxigenin-labeled antibodies. Appl Environ Microbiol. 2006;72(2):1231-1238. doi:10.1128/AEM.72.2.12311238.2006

31. Stanker LH, Merrill P, Scotcher MC, et al. Development and partial characterization of high-affinity monoclonal antibodies for botulinum toxin type A and their use in analysis of milk by sandwich ELISA. J Immunol Methods. 2008;336(1):1-8. doi:10.1016/j.jim.2008.03.003

32. Ayyar BV, Tajhya RB, Beeton C, et al. Antigenic sites on the $\mathrm{HN}$ domain of botulinum neurotoxin A stimulate protective antibody responses against active toxin. Sci Rep. 2015;5:15776. Published 2015 Oct 28. doi:10.1038/srep15776

33. Lee BS, Huang JS, Jayathilaka LP, et al. Antibody Production with Synthetic Peptides. Methods Mol Biol. 2016;1474:25-47. doi:10.1007/978-1-4939-6352-2_2

34. Lipman NS, Jackson LR, Trudel LJ, et al. Monoclonal Versus Polyclonal Antibodies: Distinguishing Characteristics, Applications, and Information Resources, ILAR Journal. 2005;46:258-268. https://doi.org/10.1093/ilar.46.3.258 